\title{
PERSEPSI MASYARAKAT TENTANG PARTISIPASI PEREMPUAN DALAM KEANGGOTAAN LEGISLATIF DI KECAMATAN PARENGGEAN
}

\author{
Betty Karya \\ Fakultas IImu Sosial dan IImu Politik Universitas PGRI Palangka Raya \\ (email: betykarya@gmail.com) \\ Puspa Pandini \\ Fakultas IImu Sosial dan IImu Politik Universitas PGRI Palangka Raya
}

\begin{abstract}
Abstrak
Penelitian ini bertujuan untuk mengetahui dan menjelaskan persepsi masyarakat tentang partisipasi perempuan dalam keanggotaan legislatif di lingkungan I Kelurahan di Kecamatan Parenggean. Penelitian ini menggunakan metode deskriptif dengan pendekatan kualitatif. Populasi dalam penelitian ini adalah masyarakat lingkungan I Kelurahan di Kecamatan Parenggean yang terdiri dari RT. 001. RT. 002, RT. 003 yang terdaftar sebagai pemilih tetap. Instrumen pengumpulan data menggunakan wawancara, observasi dan dokumentasi

Hasil Penelitian: a) Bahwa persepsi masyarakat terhadap caleg perempuan yang mencalon sebagai anggota legislatif yaitu masih ada keragu-raguan terhadap kemampuan menjadi wakil rakyat di DPRD nantinya, kurangnya sosialisasi dari caleg perempuan terhadap masyarakat sehingga menimbulkan persepsi masyarakat kurang menimbulkan pengaruh dan kurang dikenal oleh calon pemilih. b) Anggota legislatif perempuan di kabupaten serdang bedagai masih banyak menemui kendala disana sini. Salah satu penyebabnya yaitu: disebabkan masih kuatnya budaya patriarki atau anggota legislative laki-laki yang mendominasi dalam peran kepemimpinan politik yang telah melekat bagi setiap anggota legislatif sehingga sering kali ketika melakukan program kerja masih menemui kendala dan anggota legislatif perempuan itu merasa tersingkirkan. c) Faktor-faktor penghalang keterwakilan perempuan dilembaga legislatif, yaitu: Hambatan Kultural, Hambatan Sosial, Hambatan Ekonomi, Hambatan Politik
\end{abstract}

\section{Kata kunci : Persepsi, Partisipasi Masyarakat}

\section{Pendahuluan}

Indonesia sebagai negara yang merdeka diharapkan mampu menjadi negara yang terbuka terhadap pendapat atau masukkan dari warga negaranya. Kemerdekaan mengemukakan pendapat menjadi hal yang penting bagi setiap warga negara tanpa terkecuali baik secara langsung maupun tidak langsung guna

\section{Jurnal Sociopolitico}


mempengaruhi maupun memperbaiki kebijakan tertentu.

Kemerdekaan menyampaikan pendapat adalah hak setiap warga Negara untuk menyampaikan pikiran dengan lisan, tulisan dan sebagainya secara bebas dan bertanggung jawab sesuai dengan ketentuan peraturan perundang-undangan yang berlaku (pasal 1 ayat 1 UU No 9 Tahun 1998 tentang kemerdekaan menyatakan pendapat dimuka umum).

Pasal 28 UUD 1945 menyatakan bahwa, "Kemerdekaan berserikat dan berkumpul, mengeluarkan pikiran dengan lisan dan tulisan dan sebagainya ditetapkan dengan Undang-Undang”. Mengemukakan pendapat juga merupakan bagian dari partisipasi warga negara dalam pemerintahan, sesuai dengan pasal 27 ayat 1 UUD yang menyatakan bahwa, "Segala warga negara bersamaan kedudukannya di dalam hukum danpemerintahan dan wajib menjunjung hukum dan pemerintahan itu dengantidak ada kecualinya."

Sesuai dengan ketentuan UndangUndang dan pasal tersebut, maka kitadapat memahami bahwa setiap warga negara wajib dan berhak ikut serta dalam pemerintahan untuk dapat mengemukakan pendapat dalam pengambilan suatu kebijakan tanpa terkecuali, baik warga negara laki-laki maupun perempuan.

Perempuan sebagai bagian dari negara Indonesia, diperbolehkan dan diharapkan partisipasinya dalam pemerintahan supaya kebijakan yang menyangkut hak dan kawajiban perempuan dapat terakomodir. Bahkan, terdapat undang-undang yang memperjelas adanya hak politik bagi perempuan, yaitu dalam pasal 43 Undang-Undang Nomor 39 Tahun 1999 yang menyatakan bahwa:

1. Setiap warga negara berhak untuk dipilih dan memilih dalam pemilihan umum berdasarkan persamaan hak melalui pemungutan suara yang langsung, umum, bebas, rahasia, jujur, dan adil sesuai denga ketentuan peraturan perundang-undangan.

2. Setiap warga negara berhak turut serta dalam pemerintahan dengan langsung atau dengan perantara wakil yang dipilihnya dengan bebas, menurut cara yang ditentukan dalam peraturan perundang-undangan.

3. Setiap warga negara dapat diangkat dalam setiap jabatan pemerintahan. Undang-Undang Nomor 39 Tahun 1999 juga secara khusus mengatur mengenai hak perempan dalam Bab III bagian ke-9 tentang hak wanita, pasal 46 yang menyatakan bahwa "sistem pemilihan umum, kepartaian, pemilihan anggota badan legislatif, dan sistem pengangkatan dibidang eksekutif, yudikatif harus menjamin keterwakilan wanita sesuai persyaratan yang ditentukan". Terlebih lagi, undang-undang pemilu pun sudah sudah mengesahkan aturan yang menyertakan aspirasi kaum perempuan pada pasal 65 ayat 1 Undang-Undang Nomor 12 Tahun 2003 yang mengatur keterwakilan perempuan sekurangkurangnya $30 \%$. Namun, pada kenyataannya partisipasi perempuan dalam pemerintahan khususnya lembaga legislatif masih kurang dari kuota $30 \%$.

Perempuan menjadi bagian dari politik dan bisa masuk dalam keanggotaan legislatif tentu tidak hanya dari keinginan dan usaha perempuan itu sendiri, namun juga bergantung pada kepercayaan masyarakat terhadap kaum perempuan untuk dapat memimpin. Masyarakat di suatu daerah khususnya masyarakat yang terdaftar sebagai pemilih dalam pemilu

\section{Jurnal Sociopolitico}


maupun pemilukada, diharapkan mampu memberikan kepercayaan dan kesempatan dengan memilih perempuan yang mencalonkan diri sebagai anggota pemerintahan atau legislatif. Perempuanperempuan yang menyadari pentingnya partisipasi perempuan dalam politik tentu membutuhkan dukungan dari masyarakat. Persepsi masyarakat menjadi penting guna terbukanya kesempatan bagi kaum perempuan.

Jumlah perempuan yang berminat untuk berpartisipasi dalam politik dapatkita lihat dari kesadaran hak mereka untuk dapat direkrut oleh partai politik lalu mencalonkan diri sebagai pejabat pemerintahan untuk dipilih pada saat pemilu maupun pemilukada.

Partai politik memang di harapkan melakukan perekrutan terhadap perempuan hingga mencapai $30 \%$. Seperti yang diungkapkan oleh Komisioner Komisi Pemilihan Umum Kotawaringin Timur, "Rata-rata ketercapaian keterwakilan perempuan di daftar calon legislatif tetap yang bertarung pada pemilu 2014 sudah bagus, di atas $30 \% "$ Amanat Undang-undang mengenai keterwakilan perempuan di parlemen memiliki tujuan yang bagus, yaitu meningkatkan tingkat partisipasi perempuan dalam keputusan politik. Sebagai turunan dari landasan tersebut, partai memiliki beban berat untuk fokus melakukan kaderisasi terencana terhadap kader perempuan mereka agar dapat berperan lebih optimal mencapai tujuan tersebut. Tidak asal memilih hanya untuk memenuhi kuota.

Perkembangan kesadaran perempuan untuk berpartisipasi sebagai anggota legislatif seharusnya dibarengi dengan antusiasme masyarakat untuk memilih calon legislatif perempuan. Masyarakat diharapkan memiliki persepsi yang baik terhadap kehadiran perempuan yang mencalonkan diri sebagai anggota pemerintahan atau legislatif.

\section{Metode Penelitian}

Penelitian ini menggunakan metode kualitatif dengan jenis penelitian deskriptif.

Penelitian kualitatif merupakan penelitian yang dimaksud untuk memahami fenomena tentang apa yang dialami oleh subyek penelitian misalnya perilaku, persepsi, motivasi, tindakan yang lain-lain secara holistik dan dengan cara deskripsi dalam bentuk kata-kata dan bahasa, pada suatu konteks khusus yang alamiah dan dengan memanfaatkan berbagai metode alamiah itu sendiri. Penelitian skripsi ini bersifat kpustakaan dan lapangan. Karena data-data yang akan di peroleh berasal dari sumber literature (libray Research) kemudian akan juga di peroleh dari lapangan (Field Research).

\section{Hasil dan Pembahasan}

\section{Persepsi Masyarakat Tentang Partisipasi Perempuan Dalam Keanggotaan Legislatif}

Keterwakilan perempuan di kursi legislatif DPRD Kabupaten Kota Waringin Timur tentu sudah menjalankan tugas dan wewenangnya selama menduduki kursi jabatan tersebut, Peneliti telah melakukan wawancara kepada beberapa Masyarakat di Parenggean mengenai presepsi Masyarakat tentang partisipasi perempuan dalam keanggotaan legislatif.

Pandangan Anto, Masyarakat parenggean, mengatakan bahwa hak politik perempuan di DPRD Kabupaten

\section{Jurnal Sociopolitico}


Kotawarigin Timur masih rendahnya tingkat partisipasi keikutsertaan kaum perempuan yang menjadi anggota legislatif di DPRD Kabupaten Kotawaringin Timur, hanya segelintir perempuan yang maju sebagai anggota legislatif, dikarenakan kurangnya kepercayaan diri serta rendahnya wawasan terhadap bidang politik.

Tentu para anggota legislatif perempuan yang menjalankan tugas dan wewenangnya akan ada mengalami kendala selama menduduki kursi jabatan di DPRD Kabupaten Kotawaringin Timur, dalam pandangan Tutik, asal Parenggean, mengatakan banyak menemui kendala khususnya di kabupaten Kotawaringin Timur ini. Salah satu penyebabnya yaitu masih kuatnya budaya patriarki atau anggota legislatif laki-laki yang mendominasi dalam peran kepemimpinan politik yang telah melekat bagi setiap anggota legislatif sehingga sering kali ketika melakukan program kerja masih menemui kendala dan anggota legislatif perempuan itu merasa tersingkirkan. Tutik juga menambahkan karena adanya faktor internal dan faktor eksternal. Faktor internal disini Tutik katakan bahwa timbulnya rasa kurang percaya diri, kurang berani berperan aktif dalam kegiatan politik. Selanjutnya dari faktor eksternalnya itu adalah hambatan dari berbagai norma kultural dan struktural yang tidak menguntungkan legislatif perempuan.

Pemerintah

Kabupaten

Kotawaringin Timur telah memberikan kuota $30 \%$ terhadap anggota legislatif perempuan, ini adalah peluang yang cukup besar untuk para perempuan dalam kesetaraan gender, namun timbul disini masalahnya $30 \%$ itu pun tidak dapat terpenuhi, menurut Sekcam Parenggean, ini di akibatkan kurangnya pemahaman akan politik terhadap perempuan di Kabupaten Kotawaringin Timur. Dalam pandangan Sekcam, untuk menuntut kesetaraan gender karena dikasih $30 \%$ aja tidak dapat terpenuhi karena SDM perempuan di kabupaten Koawaringin Timur ini dianggap masih lemah, dan kemampuan perempuan tidak berkualitas, bagaimana mencukupi kuota 30\%. Dilihat dari pemilu 2019 ternyata perempuan yang ingin memilih itu tidak memilih caleg perempuan, melainkan memilih laki-laki karena kesadaran berpolitik perempuan itu kurang dan faktor penampilan disini juga dijadikan suatu kendala. Kampanye yang diadakan oleh calon legislatif perempuan itu tidak gencar seperti calon legislatif laki-laki, kurangnya pengaruh calon legislatif perempuan untuk mempengaruhi perempuan yang memilih untuk memilih calon legislatif perempuan.

Dari pendapat diatas dapat disimpulkan bahwa persepsi masyarakat terhadap caleg perempuan yang mencalon sebagai anggota legislatif yaitu masih ada keragu-raguan terhadap kemampuan menjadi wakil rakyat di DPRD nantinya, kurangnya sosialisasi dari caleg perempuan terhadap masyarakat sehingga menimbulkan persepsi masyarakat kurang menimbulkan pengaruh dan kurang dikenal oleh calon pemilih.

\section{Faktor-Faktor Penghalang Keterwakilan Perempuan Di Lembaga Legislatif Kotawaringin Timur}

Perjuangan panjang kaum perempuan Indonesia dalam electoral proses tidak terhenti ketika perempuanperempuan ini telah mampu memenuhi kuota 30 persen tersebut. karena banyak sekali legislatif yang membuat perempuan

\section{Jurnal Sociopolitico}


Indonesia diluar parlemen untuk harus lebih bersabar menunggu hasil dan prestasi dari para wakil mereka diparlemen. Dalam tulisannya, Ani Soetjipto, memperlihatkan beberapa ironi dari kebijakan afirmatif yang ada di Indonesia. Pertama seperti yang dijelaskan sebelumnya bahwa perempuan anggota parlemen saat ini mempunyai modal dan jaringan yang memadai namun minim modal politik. Minimnya sentuhan langsungdengan kelompok marjinal membuat amat sulit berharap agar mereka akan memahami sepenuhnya kepentingan dan aspirasi kelompok ini. (Soetjipto, 2015).

Kenyataan lain yang harus diperhitungkan adalah perempuan yang duduk dilegislatif maupun DPRD saat ini bukanlah yang berlatar belakang aktivis dan banyak bersentuhan dengan isu pemberdayaan kelompok marjinal. Mayoritas mereka ini sayangnya sangat minim sekali bersentuhan dengan organisasi gerakan perempuan dan kurang paham dengan isu gender maupun perjuangan demokratisasi di Indonesia dimana perempuan adalah integral dalam perjuangan tersebut.

Menelaah kiprah perempuan dalam bidang organisasi, tidak terlepas dari situasi masyarakat disekitarnya. Masyarakat terdiri berbagai kelas atau lapisan yang berbeda-beda pula. Terbentuknya lapisan-lapisan atau kelas dalam masyarakat yaitu lapisan atas dan bawah menunjukkan kelompok yang ada dalam masyarakat itu. hal ini terjadi karena ketergantungan kelas bawah pada kelas diatasnya. Salah satu akses yang menciptakan lapisan atas dan bawah terjadi pula dalam masyarakat Indonesia. Penjajahan sosial ekonomi yang juga diikuti dengan penyebaran agama, memperkuat kedudukan lapisan atas bawah. Ajaran-ajaran tradisi tentang manusia dan perempuan disebarluaskan sehingga sangat mempengaruhi situasi sosial ekonomi maupun ideologi.

Ajaran mengenai perempuan yang sebenarnya khusus diperuntukkan bagi para putri keraton, juga mempengaruhi masyarakat pada umunya. Ajaran yang diperuntukkan bagi orang-orang dari suku jawa dan dikalangan atas, namun pengaruhnya juga meluas. Ajaran yang menyatakan bahwa dalam kehidupan keluarga sehari-hari, ayah merupakan figur yang harus dilayani dan didahulukan, ibu harus tunduk serta patuh pada ayah dan anak-anak perempuan diberi tugas dalam urusan pelayanan. Semuanya ini merupakan ciri dan tradisi ketergantungan - Selain itu hambatan yang bersifat situasional meliputi masalah keibuan seperti tanggung jawab kepada anak-anak dirumah merupakan hambatan yang paling serius bagi perempuan untuk membuka akses untuk mencapai jabatan politik maupun pemerintahan.

Ironi kedua adalah kesenjangan pemaknaan politik yang "tidak nyambung" diantara mereka yang berjuang diarena politik (parpol dan parlemen). Pemahaman tentang politik masih kental diwarnai dengan pemahaman lama dan kuno yang melihat politik selalu dalam artian formal (parpol, parlemen, undang-undang, dst). Politik belum dipahami sebagai sesuatu yang relevan dengan kehidupan perempuan sehari-hari. Hal ini disebutkan Ani disebabkan oleh terlalu banyaknya kerja dipusat dan upaya pelatihan dan penguatan yang rancu dengan pemikiran.

Kondisi perempuan diparlemen dan parpol pun semakin diperparah ketika mereka terseret dengan budaya mankulinitas yang ada didalam parpol. Politik bagu mereka adalah perebutan

\section{Jurnal Sociopolitico}


kursi kekuasaan, karena mereka seperti itulah politik diperlihatkan dalam kehidupan parlemen dan parpol. Gagasan tentang pemberdayaan kelompok marjinal, pemihakan kepada kalangan tersisih, serta suaradan kepentingan konstituen adalah gagasan yang asing bagi mereka. Permasalahan perempuan dan dunia politik adalah persoalan yang sangat kompleks. Perempuan yang berada dua dunia sekaligus memiliki beban yang lebih besar. (Tari Siwi Utami, 2013).

Tidak jarang mereka justru mengorbankan kehidupan pribadinya demi perjuangan kesetaraan bagi kaumnya. Perempuan harus menyadari dan mampu mengatasi kendala-kendala yang umumnya muncul ketika mereka hendak terlibat aktif dalam dunia politik. Secara internal dapat disimpulkan bahwa kendala yang umunya dihadapi oleh perempuan disebabkan oleh tiga hal. Pertama, adanya sikap mental yang lemah. Perempuan yang meskipun telah duduk dilegislatif cenderung lemah dalam memperjuangkan kepentingan kaum perempuan. Hal ini disebabkan oleh latar belakang pendidikan yang tidak tinggi serta pengetahuan yang tidak memadai.

Menurut teori kepemimpinan Mc Celland, dalam hal Achievement Motivation (Motivasi Keberhasilan), yang membedakan antara motivasi untuk mendekati sukses dengan motivasi untuk menghindari kegagalan, perempuan juga mengalami ketidakpastian, menurut Hommer, dibedakan suatu kategori ketiga ialah bukan "hope for succes, atau fear for failure" akan tetapi "fear for succes", pada perempuan khususnya karena dirasakan antara keberhasilan dengan feminitas dianggap terdapat kontradiksi. Jika ditelaah keberhasilan yang telah dicapai perempuan-perempuan pahlawan dan penguasa serta ilmuan yang tersebut sebelumnya, pendapat Mc Celland dan Hommer tersebut masih diragukan, kesimpulan yang dapat diambil adalah bahwa perempuan dapat lebih maju dan berhasil jika cara didikan yang diterima oleh mereka baik formal maupun non formal sama dengan pendidikan yang diterima oleh kaum lelaki.

Jika faktor-faktor penghambat partisipasi perempuan dalam politik sebagian besar adalah sama dengan hal-hal tersebut, antara lain : didikan yang diberlakukan pada perempuan untuk lebih berkiprah disekitar rumah tangga saja, bahwa bidang politik tidak atau kurang sesuai bagi perempuan karena dianggap terlalu keras, penuh persaingan, bertolak belakang dengan sifat perempuan, yang dianggap sebagai makhluk yang emosional, pasif, lemah, dependen, dekoratif, tidak asertif dan tidak kompeten dalam bidang tersebut. Disamping itu masih ada sebagian masyarakat yang menilai keberhasilan perempuan itu lebih dipandang dari kemampuannya mengatur rumah tangga dan anak-anak sehingga jika seorang perempuan berhasil dalam karier, namun rumah tangganya kurang harmonis, perempuan yang disalahkan. Pandangan tersebut bukan hanya dari pihak lai-laki saja bahkan kaum perempuan sendiri juga terbiasa dengan situasi itu dan merasa kurang sesuai dengan dunia politik yang keras tersebut. Selain itu tidak dapat dipungkiri bahwa masih ada sebagian kaum laki-laki yang memang masih belum sempat dapat menerima hadirnya kaum perempuan dalam dunia politik.

Partai politik belum sepenuhnya athome dengan kewajiban $30 \%$ mencalonkan perempuan sebagai caleg (calon anggota legislatif) nomor jadi. Yang ada perempuan justru dipasang

\section{Jurnal Sociopolitico}


sebagai simbol akomodatif, dengan nomor-nomor sepatu yang susah meloloskan perempuang menuju kursi parlemen. Model yang dipakai partai pada perempuan hanya simbolik atau lips service sebagai strategi dari partai yang ujung-ujungnya menarik konstituen memilih partai yang tidak tau apa alasan perempuan dipartai cuma dipajang, kesan bahwa perempuan tidak memiliki syarat standar dan cenderung lemah dan terbatas adalah argumentasi yang bersifat apologi atau mencari-cari kelemahan perempuan saja. Sikap ambivalensi partai yang cenderung mendua dalam melihat perempuan adalah gambaran dari sikapmasyarakat kita yang belum sepenuhnya melihat perempuan sebagai kekuatan perubahan dalam masyarakat.

Paradigma lama bahwa perempuan sebagai kaum yang lemah dan terbatas serta hanya berfungsi sebagai pelengkap kaum adam, masih cukup dominan menghinggapi cara berfikir mayoritas masyarakat kita. Di era globalisasi ini, seharusnya kaum perempuan bukan lagi diposisikan sebagai warga negara kelas dua, dibawah bayang-bayang kekuasaan kaum laki-laki, tetapi harus diposisikan dan dijadikan sebagai mitra yang mempunyai harkat, martabat serta derajat yang sama. Politik yang santun dan dewasa dalam masyarakat kita memang masih sulit diperankan oleh siapapun. Dewasa ini justru menonjol adalah politik yang menghalalkan segala cara demu mencapai kepentingan dan target yang sifatnya oportunistik dan finansial semata. Itu sebabnya politisasi atas nama agama, tradisi dan etnisasi yang mengemuka dan sering menjadi biang konflik horizontal tak lebih dari kreasi yang namanya politik atas nama kepentingan serta tujuan tertentu dalam melanggengkan status quo itu sendiri. Politik yang penuh persaingan inilah yang harus dihadapi bila perempuan mau terjun memilih politik sebagai pilihan pengabdian dalam membantu merubah wajah politik Indonesia yang coreng moreng khususnya orang-orang yang ingin menjadi katalisator-katalisator perubahan bagi perempuan lain yang masih banyak tertinggal serta banyak pula sebagai korban-korban kekerasan yang belum tersentuh oleh kebijakan-kebijakan Negara sampai sekarang ini. (Asaruddin Umar, 2014).

Beberapa faktor-faktor penghalang keterwakilan perempuan dilembaga legislatif kabupaten Kotawaringin Timur:

a. Hambatan Kultural

Mayoritas masyarakat kita, masing didominasi oleh cara pandang dan sikap yang cenderung melihat serta memperlakukan kaum perempuan sebagai pelengkap kaum laki-laki. Persepsi semacam ini, tidak jarang pada akhirnya melihat dan menempatkan kaum perempuan sebagai pelengkap kaum lakilaki bahkan dalam tingkat tertentu hanya dilihat sebagai objek semata.

Secara cultural dimana sudut pandang patrinial (laki-laki dilihat lebih superior) menjadi acuan utama dalam melihat dan menempatkan perempuan, telah menyebabkan peranan perempuan selalu dikonotasikan dengan hal-hal yang bersifat pelengkap kaum laki-laki, bukan sebagai mitra yang mempunyai kedudukan sejajar sehingga berhak mendapatkan peluang yang sama diberbagai bidang sendi kehidupan. Hambatan kultural merupakan hambatan yang cukup fundamental kerena kultul/budaya akan membentuk persepsi dan persepsi yang pada akhirnya akan bermuara pada pola perilaku dalam kehidupan sehari-hari. Oleh sebab itu, sudah menjadi kewajiban

\section{Jurnal Sociopolitico}


bersama untuk meluruskan cara pandang budaya yang kurang tepat dalam memahami dan memandang kaum perempuan sehingga kaum perempuan dapat memainkan peran dan fungsinya lebih maksimal lagi.

b. Hambatan Sosial

Struktur sosial masyarakat kita yang cenderung menempatkan perempuan sebagai "warga negara no 2 dibawah kaum laki-laki", telah memberi dampak tersendiri bagi keberadaan perempuan ditengah-tengah masyarakat kita, termasuk dalam konteks hubungan suami istri dilingkungan rumah tangga. Perempuan masih sering diposisikan sebagai pihak yang harus bersikap "menerima" tanpa perlawanan (reserve) sehingga pada akhirnya kaum perempuan lebih dilihat sebagai objek daripada sebagai subjek yang menjadi mitra kaum laki-laki. Kekerasan dalam rumah tangga yang sering menempatkan perempuan pada posisi lemah, adalah sebuah contoh nyata imana kaum perempuan tidak mempunyai kekuatan untuk melawan ketidakadilan dan kesewenang-wenangan dari kaum laki-laki. Lahirnya UU KDRT (Kekerasan Dalam Rumah Tangga) membuktikan bahwa sering sekali terjadi kekerasan terhadap perempuan yang disebabkan karena cara pandang kaum pria terhadap perempuan. Begitu pula dalam kasus hubungan suami istri, kaum perempuan cenderung diperlakukan tidak sejajar dalam posisi bargaining yang lemah sehingga dominasi dan ego kaum laki-laki seolah-olah mendapatkan tempat yang lebih baik. Padahal dalam konteks, penularan HIV/AIDS misalnya, kaum perempuan mempunyai resiko 2,5 kali lebih besar dari kaum laki-laki. (Ali Hakim Husin, 2013).

c. Hambatan Ekonomi
Dalam masalah karir, wanita juga masih mengalami diskriminasi diberbagai hal sehingga kaum perempuan tidak jarang diberlakukan kurang adil dan tidak proporsional. Dalam kasus PHK misalnya, kaum perempuan akan menjadi pihak yang mempunyai resiko lebih besar dibandingkan kaum laki-laki. Begitu pula dalam penetapan standar gaji, tidak jarang kaum perempuan tidak mendapatkan haknya secara proporsional.

d. Hambatan Politik

Hambatan politik merupakan salah satu hambatan yang cukup besar yang dihadapi kaum perempuan di Indonesia. Hal ini tidak hanya tercermin dalam produk perundang-undangan maupun peraturan yang cenderung bersifat "maskulin", dimana segala sesuatu pokok masalah lebih dilihat dari kacamata kaum laki-laki, tetapi menyangkut pula masih terbatasnya ruang yang tersedia bagi kaum perempuan untuk berkiprah dalam posisi jabatan-jabatan publik. Walaupun akhirakhir ini sudah mulai terlihat adanya keberpihakan dan pengakuan akan perlunya peranan kaum perempuan dalam politik, namun kebijakan-kebijakan tersebut masih diberlakukan "setengah hati" dan belum maksimal.

Oleh sebab itu tidaklah mengherankan apabila jumlah perempuan yang terjun dalam dunia politik yang selalu diidentikan dengan dunia laki-laki ini, masih sangat terbatas. Begitu pula jumlah perempuan yang dapat mencapai posisi puncak dalam jenjang birokrasi dipemerintahan, masih jauh dari harapan apabila melihat komposisi jenis kelamin warga negara Indonesia tidak kurang dari $51 \%$ nya adalah perempuan.

\section{Jurnal Sociopolitico}




\section{Kesimpulan}

a) Bahwa persepsi masyarakat terhadap caleg perempuan yang mencalon sebagai anggota legislatif yaitu masih ada keragu-raguan terhadap kemampuan menjadi wakil rakyat di DPRD nantinya, kurangnya sosialisasi dari caleg perempuan terhadap masyarakat sehingga menimbulkan persepsi masyarakat kurang menimbulkan pengaruh dan kurang dikenal oleh calon pemilih.

b) Anggota legislatif perempuan di kabupaten serdang bedagai masih banyak menemui kendala disana sini. Salah satu penyebabnya yaitu: disebabkan masih kuatnya budaya patriarki atau anggota legislative lakilaki yang mendominasi dalam peran kepemimpinan politik yang telah melekat bagi setiap anggota legislatif sehingga sering kali ketika melakukan program kerja masih menemui kendala dan anggota legislatif perempuan itu merasa tersingkirkan.

c) Faktor-faktor penghalang keterwakilan perempuan dilembaga legislatif, yaitu: Hambatan Kultural, Hambatan Sosial, Hambatan Ekonomi, Hambatan Politik

\section{Referensi}

Arikunto, Suharsimi. 2010. Prosedur Penelitian Suatu Pendekatan Praktik. Jakarta: Rineka Cipta.

Astuti, Widi. 2008. Partisipasi Komite Sekolah dalam Penyelenggaraan Kegiatan Ekstrakurikuler di SD Negeri Se Kecamatan Godean. Skripsi. FIP UNY

Echols, John.M. dan Hassan Shadily. 2011. Kamus Inggris Indonesia. Jakarta: PT. Gramedia
Fasli Djalal dan Dedi Supriadi. 2001. Reformasi Pendidikan Dalam Konteks Otonomi Daerah. Adicita Yogyakarta

HAR, Tilaar. 2009. Paradigma Baru. Pendidikan Nasional. Rineka. Jakarta

Rakhmat, Jalaluddin. 2011. Psikologi Komunikasi. PT Remaja Rosdakarya: Bandung

Khofifah Indar P. 2015. Nu, Perempuan Indonesia. Nuansa Cendikia : Bandung

Miriam Budiardjo. 2007. Partisipasi dan Partai Politik. Yayasan Obor Indonesia : Jakarta

Mukarom, Zaenal. 2004, Perempuan dan Politik. Bandung: Alfabeta

Mulyana, Dedi, 2005. Ilmu Komunikasi Suatu Pengantar. Jakarta: PT. Gramedia

Parawansa, Indar Khofifah (2009) Meningkatkan Partisipasi Politik Perempuan di Indonesia, Jakarta.

Remiswal 2013. Menggugah partisipasi gender dilingkungan komunitas lokal. Graha: Yogyakarta

Robbins, S.P. (2001). Psikologi Organisasi, (Edisi ke-8). Jakarta: Prenhallindo.

Rosilayati. 2014. Persepsi Orang Tua Terhadap Pernikahan Dini di Kelurahan Garuntang Kecamatan Bumi Waras Kota Bandar Lampung Tahun 2013.

Sapari Ratna, 2006. Perempuan Kerja dan Perubahan Sosial. Pustaka Utama Grafitri. Jakarta

Sarwono, W Sarlito. 2010. Psikologi Sosial. Jakarta: Selemba Humanika.

Sedarmayanti. 2003. Good Governance (Kepemerintahan Yang Baik) Dalam Rangka Otonomi Daerah. Bandung: Mandar Maju

\section{Jurnal Sociopolitico}


Siti Irene A.D. 2011. Desentralisasi dan Partisipasi Masyarakat dalam Pendidikan. Pustaka Pelajar: Yogyakarta.

Soekanto, Soerjono. 2006. Sosiologi Suatu Pengantar. Jakarta: PT Gravindo.

Sugiyah. 2010. Partisipasi Komite Sekolah dalam penyelenggaraan Rintisan Sekolah Bertaraf Internasional di Sekolah Dasar Negeri IV Wates,. Tesis. PPs UNY. Kabupaten Kulon Progo.

Sugiyono. 2010. Metode Penelitian Pendidikan Pendekatan Kuantitatif, Kualitatif dan $R \& D$. Alfabeta: Bandung.

Suharto, Edi. 2003. Analisis Kebijakan Publik: Panduan Praktis Mengkaji Masalah dan Kebijakan Sosial. Bandung: Alfabeta.

Sukardi. 2009. Metodologi Penelitian Pendidikan. Jakarta: Bumi Aksara

Sunarno, Siswanto. 2014. Hukum Pemerintahan Daerah di Indonesia.. Sinar Grafika : Jakarta

Waluya, Bagja. 2007. Sosiologi. Bandung: Setia Purnama Inves.

Willie Wijaya. 2004. Kamus Lengkap Indonesia. Bintang Jaya : Semarang. 